\title{
Bidder Behavior in Repo Auctions without Minimum Bid Rate: Evidence from the Bundesbank
}

\section{Tobias Linzert}

(Goethe-University Frankfurt)

\section{Dieter Nautz}

(Goethe-University Frankfurt)

\section{Jörg Breitung}

(University of Bonn)

Discussion paper 13/03

Economic Research Centre

of the Deutsche Bundesbank 
Deutsche Bundesbank, Wilhelm-Epstein-Strasse 14, 60431 Frankfurt am Main, Postfach 1006 02, 60006 Frankfurt am Main

Tel +4969 9566-1

Telex within Germany 41227, telex from abroad 414431, fax +49 695601071

Please address all orders in writing to: Deutsche Bundesbank,

Press and Public Relations Division, at the above address or via fax No. +4969 9566-3077

Reproduction permitted only if source is stated.

ISBN 3-935821-63-8 


\begin{abstract}
A distinguishing feature of the ECB's monetary policy setup is the preannouncement of a minimum bid rate in its weekly repo auctions. However, whenever interest rates are expected to decline, the minimum bid rate is viewed as too high and banks refrain from bidding, severely impeding the ECB's money market management. To shed more light on banks' underbidding, we perform a panel analysis of the bidder behavior in the repo auctions of the Bundesbank where no minimum bid rate was set. Our results indicate that neither bank's participation nor the submitted bid amount is significantly affected by an expected rate cut. This suggests that abandoning the minimum bid rate might increase the efficiency of the ECB's money market management.
\end{abstract}

Keywords: Monetary Policy Instruments, Auctions, Bidder Behavior, Panel Analysis

JEL-Classification : $\quad$ C23, D44, E52 


\section{Zusammenfassung}

Nach dem Vorbild der Deutschen Bundesbank spielen wöchentliche Repo-Auktionen (die Hauptrefinanzierungsgeschäfte) eine zentrale Rolle für die Geldpolitik der Europäischen Zentralbank. Das dort bereitgestellte Refinanzierungsvolumen bestimmt die Liquidität des Bankensektors und der dabei von der EZB gesetzte Mindestbietungssatz gilt als geldpolitischer Leitzins für die Zinssätze am Interbankengeldmarkt.

Ausgangspunkt dieser Arbeit ist die Beobachtung, dass die Verwendung eines Mindestbietungssatzes bei Zinssenkungserwartungen $\mathrm{zu}$ einem unerwünschten Unterbieten der Banken führt. Im Extremfall eines Bieterstreiks wird das Liquiditätsmanagement der EZB merklich behindert.

Thema dieser Studie ist das Bieteverhalten der Banken bei den Repo-Auktionen der Bundesbank, die in den 90er Jahren bei den Zinstendern auf die Vorgabe eines Mindestbietungssatzes verzichtete. Auf der Grundlage individueller Bietedaten wird mit Hilfe panelökonometrischer Methoden untersucht, wie verschiedene Faktoren, wie zum Beispiel Zinserwartungen, Opportunitätskosten, Zinsunsicherheit oder der Bankentyp die Teilnahmeentscheidung und das Bietevolumen einer Bank bei einem Zinstender ohne Mindestbietungssatz bestimmen. Die empirischen Ergebnisse zeigen, dass Zinserwartungen, auch bei den Bundesbank Auktionen das Bieteverhalten der Banken beeinflussten. Allerdings verursachen Zinserwartungen im Gegensatz zur EZB keine abrupten Änderungen im Bieteverhalten und auch keine Bieterstreiks. Offenbar bewirkte das Fehlen eines Mindestbietungssatzes, dass sich die Gebote der Banken und damit der Reposatz und die Zinssätze am Interbankengeldmarkt graduell an ein verändertes Zinsniveau anpassen konnten. 


\section{Contents}

1 Introduction 1

2 Data and theoretical predictions 2

2.1 The bidding data 2

2.2 Variables and theoretical predictions 3

3 Empirical results $\quad 5$

3.1 The participation decision of banks 5

$\begin{array}{lll}3.2 & \text { The bid amount } & 8\end{array}$

4 Conclusions 11

$\begin{array}{ll}\text { References } & 13\end{array}$ 


\section{List of Tables and Figures}

Table 1: Distribution of Average Bid Volume

Table 2: $\quad$ Distribution of Number of Bids

Table 3: $\quad$ Participation Frequency

Table 4: $\quad$ Bank Types

Table 5: The Participation Decision of an

Individual Bank: A Panel Logit Analysis

Table 6: The Participation Decision of an Individual Bank with

Size Specific Regressors

Table 7: $\quad$ The Determinants of a Bank's Bid Amount:

A Panel Analysis

Table 8: $\quad$ The Determinants of a Bank's Bid Amount:

Tobit Model Estimation with Bank Size Specific Regressors

Figure 1: $\quad$ Interest rates in the German money market 


\section{Bidder Behavior in Repo Auctions without Minimum Bid Rate: Evidence from the Bundesbank ${ }^{1}$}

\section{Introduction}

Following the monetary policy practice of the Bundesbank, repo auctions are the predominant instrument for the ECB's money market management. A distinguishing feature of the ECB's repo auctions is the announcement of a minimum bid rate which strongly indicates the ECB's policy intentions and typically sets a floor for the short-term interest rates of the euro area. Yet, when banks expect interest rates to decrease, the current minimum bid rate is viewed as too high and banks underbid, i.e. they tend to refrain from bidding. On several occasions banks' underbidding severely hampered the ECB's liquidity management, increased interest rate volatility and obscured the monetary policy stance. ${ }^{2}$ The ECB recently announced rather involved "measures to improve the efficiency of the operational framework for monetary policy" to keep banks from underbidding, see ECB (2003a). Interestingly, however, the auction format will remain unchanged. In particular, the ECB will still pre-announce a minimum bid rate.

This paper investigates the bidding behavior of banks not constrained by a minimum bid rate. We employ a unique data set of individual bids submitted in the repo auctions of the Bundesbank where no minimum bid rate was set. Apart from the minimum bid rate, however, the repo auctions of the Bundesbank and the ECB share exactly the same rules. Therefore, the Bundesbank auctions provide us with almost a natural experiment to study the role of the minimum bid rate and the ECB's underbidding problem.

In two recent papers, Nyborg, Bindseil and Strebulaev (2002) and Scalia and Ordine (2002) investigated how banks' bidding in the ECB's repo auctions is influenced by factors such

\footnotetext{
${ }^{1}$ Financial support by the Deutsche Forschungsgemeinschaft (DFG) through NA-31020102 is gratefully acknowledged. We thank the seminar participants at the Bundesbank and the ECB for helpful comments and fruitful discussion, and the Bundesbank for providing us access to their data. Corresponding address: Goethe University Frankfurt, Department of Economics, Mertonstr. 17-21, 60054 Frankfurt am Main, Germany. Email: linzert@wiwi.uni-frankfurt.de, nautz@wiwi.uni-frankfurt.de, breitung@eos.ect.uni-bonn.de

2 For example, in the repo auctions on February 13 and April 10 in 2001 and more recently in December 2002 and March 2003, banks' underbidding prevented the ECB from injecting the necessary amount of reserves into the money market. As a result, money market rates increased sharply although anyone expected interest rates to decrease, see ECB (2001).
} 
as the level of money market rates, interest rate expectations and uncertainty. Nyborg, Bindseil and Strebulaev (2002) use aggregated bidding data to investigate the winner's curse effect and the relation between the repo rate and the secondary market ${ }^{3}$. Scalia and Ordine (2002) perform a full-blown panel analysis of banks' bidding with the focus on the empirical relevance of country specific effects. Both studies confirm the underbidding problem in the ECB's auctions but remain less explicit on its causes, in particular, the role of the minimum bid rate.

In line with Scalia and Ordine (2002) we will estimate panel regressions for the probability of bidding and a bank's individual bid amount. The latter variable is left-censored since it can only be observed if a bank actually participates in an auction. This property of the data is often neglected in the empirical literature on auctions. ${ }^{4}$ This paper accounts for the effect of censored variables using a panel tobit approach.

The remainder of the paper is organized as follows. In Section 2, we introduce the data and variables that are used in the following panel regressions. Section 3 presents the empirical analysis of banks' bidding in the Bundesbank's auctions. First, we estimate a logit model to analyze banks' participation decision. In a second step, we build on the preceding analysis employing a panel tobit model to investigate the determinants of a bank's bid amount. Section 4 gives a summary of the main results and offers some policy conclusions.

\section{Data and theoretical predictions}

\subsection{The bidding data}

The following empirical analysis is based on a unique data set of weekly repo auctions performed by the Bundesbank. We collected individual bidding data (which was not available in computer readable form) of 275 banks that had submitted their bids at the Land Central Bank of Hesse. Bidder codes allow us to track each bidder over time. Hesse contains Germany's financial center Frankfurt hosting a major part of German banks including large banks as well as a broad range of small private banks and foreign bank dependencies. Therefore, the results derived from our sample should be fairly representative for the bidding

\footnotetext{
${ }^{3}$ See also Nyborg, Rydqvist and Sundaresan (2002) for a similar study on Swedish treasury auction.

${ }^{4}$ See Scalia and Ordine (2002), but also Bjonnes (2001) who estimates bid functions for the Norwegian Treasury Bill auctions. A notable exception is Ayuso and Repullo (2001) who investigate banks' bidding in the ECB's fixed rate tenders.
} 
behavior of the German banking sector.

In many respects, banks' bidding behavior in the repo auctions of the Bundesbank and the ECB appear to be very similar. ${ }^{5}$ First, large bidders participate more often but their bids are still small relative to the total bid volume, see Table 1. Second, banks usually do not submit more than three bids per auction, see Table 2. In fact, the bid rate dispersion in the Bundesbank's repo auctions is not higher than in the repo auctions of the ECB, although there is no minimum bid rate that constrains banks' bidding. Third, there are many bidders that participate only infrequently, see Table 3 . Only 175 out of 275 Hessian banks participated at least once in the auctions covered by our data set. A similar share of active bidders is observed in the repo auctions of the ECB. In contrast to previous empirical work, we do not remove the bidders never participating in an auction to avoid distorting effects on the analysis of banks' participation decision.

Compared with the ECB, which changed the auction format only once in four years, the Bundesbank was far less reluctant to switch between fixed and variable rate tenders. ${ }^{6}$ In fact, there is only one longer period, running from April to November 1995, where the Bundesbank did not change the auction format. In this period, the Bundesbank performed its repo auctions exclusively as variable rate tender, which is the auction format used by the ECB since June $2000 .{ }^{7}$ We therefore concentrate on this period that provides 33 auctions with the standard maturity of about two weeks. Note that this period was characterized by decreasing interest rates, see Figure 1. In particular, in August 1995 the Bundesbank lowered the rate of its marginal lending facility (the Lombard rate) by 50 basis points. With regard to banks' underbidding in the repo auctions of the ECB, it will be interesting to see how banks' bidding is affected by the Bundesbank's interest rate cut.

\subsection{Variables and theoretical predictions}

Following Scalia and Ordine (2002) and Bjonnes (2001), we characterize the bidding behavior of a bank by its participation decision and the log of the individual bid amount which will be explained by various auction as well as bidder-specific factors.

\footnotetext{
${ }^{5}$ See Nyborg, Bindseil and Strebulaev (2002) and ECB (2001) for descriptive statistics on ECB auctions.

${ }^{6}$ Central banks use fixed rate tenders to provide clear signals about the current interest rate target. The impact of the auction format on interest rate uncertainty is investigated in Nautz (1998) and Manna (2002).

7 The ECB switched to the variable rate tender format in response to banks' overbidding, i.e. banks increasingly exaggerated their liquidity needs in the bids, see Nautz and Oechssler (2003).
} 
Banks' demand for repos should be affected by the cost of alternative refinancing opportunities. For example, the higher the spread defined as the difference between the expected stop out rate and the overnight rate the cheaper is the repo credit. ${ }^{8}$ Therefore, a higher spread should increase both, the probability of bidding and the bid amount. We estimated the expected stop out rate using the error correction equation implied by the cointegrating relation between the stop out rate and the overnight rate, see Appendix A.

The variable term spread is defined as the difference between the one-month rate and the overnight rate where e.g. a negative term spread indicates that interest rates are expected to decline. For the repo auctions of the ECB, expected changes of the ECB's key interest rates have a strong impact on banks' bidding behavior. In particular, when banks expect decreasing interest rates, underbidding hampers the central banks' liquidity management. According to the course of the term spread, banks clearly anticipated the reduction in the rate of the Bundesbank's marginal lending facility in August 1995. To capture possible bidding strike behavior, we introduce a dummy variable underbidding which takes the value one in the auction preceding the Bundesbank's rate cut, compare Scalia and Ordine (2002).

The interest rate uncertainty perceived at the auction day is proxied by the variable volatitity which is estimated using an EGARCH $(1,1)$ model for daily observations of the overnight rate, compare Nyborg, Rydqvist and Sundaresan (2002). Regarding the impact of uncertainty on banks' bidding, the implications of auction theory are ambiguous. On the one hand, there is the well-known 'winner's curse' effect implying that banks bid more cautious when uncertainty increases. On the other hand, according to Scalia and Ordine (2002), if the concern is the risk of losing in an auction, not winning, then higher uncertainty may induce bidders to submit larger bids at higher rates. This behavior would also be in line with the predictions of multi-period reserve management models, where higher interest rate risk increases banks' demand for reserves, see Nautz (1998).

The variable reserve fulfilment measures the liquidity need of the banking sector. Since data on the individual reserve holdings are not available it is defined as the ratio of the reserve holdings of all German banks prior to the auction and the aggregate minimum reserve requirement. If reserve holdings are low, banks should have a stronger incentive to participate in the auction. Since the Bundesbank allowed averaging over the maintenance period, this

\footnotetext{
${ }^{8}$ Note that it would be more appropriate to define the opportunity cost variable using a money market rate having the same maturity as the repo. Unfortunately, however, a biweekly money market rate, comparable to the newly introduced EONIA swap rate used in Scalia and Ordine (2002), is not available.
} 
effect might be particularly relevant in the last auction of the maintenance period. We subsequently defined the dummy variable end of period taking the value 1 if the auction is the last in the maintenance period.

Finally, we consider two bidder-specific regressors. The variable maturing allotment is defined as the log of a bank's repo volume received two weeks before. This variable captures the fact that banks often use the biweekly repo credit on a revolving basis. The dummy variables large, medium, and small characterize a bank's size as it is reflected in the average bid volume, see Table 4. We will interact these dummies with all explanatory variables to investigate how a bank's bidding behavior is influenced by its size.

\section{Empirical results}

\subsection{The participation decision of banks}

In a first step, we analyze the participation decision of an individual bank using a panel version of the logit model where the dependent variable $y_{i t}$ equals one if bank $i$ participates in auction $t \in\{1, \ldots, N\}$ and is zero otherwise. Using the logistical distribution $\Lambda$, the logit model is given by

$$
\operatorname{Prob}\left(y_{i t}=1 \mid x_{i t}\right)=\Lambda\left(x_{i t}^{\prime} \beta\right)=\frac{e^{x_{i t}^{\prime} \beta}}{1+e^{x_{i t}^{\prime} \beta}}
$$

where $x_{i t}$ and $\beta$ denote the vector of explanatory variables and the corresponding coefficients, respectively.

We opted for the random effects logit model since the Hausman-test could not reject the hypothesis that the individual effects are uncorrelated with the other regressors. The random effects model allows for the inclusion of time-invariant bidder-specific regressors like the size dummies introduced above. Our specification is corroborated by the similarity of the parameter estimates from the random and the corresponding conditional fixed effects estimation, see Table 5 .

Table 5 presents the estimation results indicating each variable's impact on the participation probability. Yet, as in any nonlinear regression the estimated coefficients do not have the familiar elasticity interpretation. To evaluate the parameter's economic significance, we report the appropriate marginal effects for the logit case, see column 2. Following Greene 
(2002), the marginal effect is calculated as

$$
\frac{\partial E\left[y_{i t} \mid x_{i t}\right]}{\partial x_{i t}}=\left\{\Lambda\left(x_{i t}^{\prime} \beta\right)\left[1-\Lambda\left(x_{i t}^{\prime} \beta\right)\right]\right\} \beta
$$

indicating the percentage point change of the probability upon a one percent increase of the explanatory variables. Since its value varies with $x$, the marginal effects are evaluated at the sample means of the regressors. In the case of a dummy variable, the derivative with respect to a small change in the variable is not appropriate. Therefore the marginal effect is given by:

$$
\text { Marginal Effect }=\operatorname{Prob}\left[y_{i t}=1 \mid \bar{x}_{i t}, d=1\right]-\operatorname{Prob}\left[y_{i t}=1 \mid \bar{x}_{i t}, d=0\right]
$$

where $d$ represents the dummy variable and $\bar{x}_{i t}$ refers to the means of the remaining explanatory variables.

According to Table 5 interest rate expectations have a significant influence on a bank's participation decision. In line with the ECB's experience, the participation probability in the repo auctions of the Bundesbank decreases when a negative term spread indicates that interest rates are expected to decrease. However, given the estimated marginal effect (0.879) of the term spread, the economic significance of rate expectations for banks' bidding behavior crucially depends on the existence of a minimum bid rate. To see this, suppose banks anticipate a rate cut by the central bank of 50 basis points. In the ECB's monetary setup, the minimum bid rate prevents the current repo rate and, thus, the overnight rate from falling. As a result, the term spread will decrease to about minus 50 basis points and banks' participation decreases by $50 \times 0.879=44 \%$. Thus, the introduction of a minimum bid rate would yield a large reduction in the number of bidders comparable to the bidder strikes actually experienced by the ECB. Yet, in the Bundesbank auctions, bids were not constraint by a minimum bid rate such that both, the repo and the overnight rate could fall in anticipation of a Lombard rate cut, see Figure 1. Therefore, the term spread could adjust smoothly and was generally much smaller (e.g. 10 basis points) than the actual rate cut. Accordingly, the impact of rate expectations for the Bundesbank auctions is rather modest $(10 \times 0.879=8.8 \%)$. Finally, the insignificant coefficient of the dummy variable underbidding underlines that the expected rate cut of the Bundesbank had no major impact on banks' participation decision.

The variable spread measuring the opportunity costs of repos exhibits a significant effect on banks' participation decision and its coefficient is plausibly signed. Particularly, if the 
expected repo rate of the central bank is high relative to the money market rate fewer banks will decide to participate in the auction. Note that the estimated coefficients of the spread and the term spread suggest that the overnight rate cancels out. The implied parameter restriction is, however, strongly rejected by the data.

The coefficient of the variable volatility is significantly negative. Yet, the marginal effect indicates that volatility's influence on a bank's participation decision is negligible. We are therefore reluctant to interpret the coefficient as evidence in favor of the winner's curse effect. If banks are short in liquidity, i.e. their reserve fulfilment is low, they should have a stronger incentive to participate in the auction. As in Scalia and Ordine (2002) this is not substantiated by our data. This plausible effect might be obscured in our estimation because we were left with aggregate data to proxy the liquidity position of an individual bank.

As expected, the variable maturing allotment has a positive effect on banks' participation demonstrating that banks use repos on a revolving basis. According to the estimated marginal effect, a 70 percent rise in the volume of the maturing repo raises a bank's participation probability by one percentage point. At a first glance, this effect appears to be small, but banks' individual allotments range between zero and 5 billion DM. Due to that large variation, the maturing allotment is a major determinant of banks' participation probability. For example, the average participation probability of a bank with zero maturing allotment is about $7 \%$ while the average probability jumps to $31 \%$ if the bank received only one million DM, the minimum allotment set by the Bundesbank.

According to the estimated effect of the end of period dummy banks' participation probability rises in the auctions performed in the last week of the maintenance period. Apparently, banks bid more often at the end of the period anticipating the increased probability of being squeezed after the auction, see Nyborg and Strebulaev (2001). The marginal effect indicates that in the last auction of the reserve period the average participation probability of a bank rises by 6 percentage points.

Finally, the coefficients of the size-dummies display the obvious fact that large banks participate more frequently in the auctions than small banks, see also Table 4. Large banks bid in the auction not only to satisfy their own liquidity needs but also to resale and actively trade reserves in the secondary market. 


\section{Size Effects on a Bank's Participation}

We now turn to analyzing the role of a bank's size on its participation decision. In order to investigate whether a bank's response to a regressor depends on its size, we interact the size dummies with all other explanatory variables. ${ }^{9}$ The results are presented in the first column of Table 6. In the second column we display the p-value of the Wald-statistics testing for the null hypothesis of no size effect.

There are significant size effects with regard to banks' response to interest rate expectations (term spread) and to expected opportunity cost (spread). For both variables, the medium-sized banks show the weakest response. The coefficients of the size-specific maturing allotment variables reflects that the seasonality of participating in an auction is more pronounced for small and medium size banks than for large banks. There is no evidence for a size effect with regard to the remaining explanatory variables. Notably, there were no significant size interactions with the underbidding dummy implying that the impact of rate cut expectations on banks' participation is small irrespective of a bank's size.

In the last column of Table 6 we report the p-values of the tests on the overall significance for each group of variables. The results of the extended logit model are very much in line with those obtained for the model without size effects, see Table 5. In particular, the extended logit model confirms the doubts on the significance of volatility for banks' participation decision.

\subsection{The bid amount}

In this section, we advance on the preceding analysis of bidders' participation decision investigating the determinants of an individual bank's bid amount. Naturally, a bank's bid volume can only be observed if the bank decides to participate in the auction. As a consequence, the variable bid amount is left-censored and ignoring this property might result in biased estimates. Following Ayuso and Repullo (2001), we employ a panel tobit model that accounts for the participation decision of each individual bank.

\footnotetext{
${ }^{9}$ Since large banks participated in almost every auction, the corresponding coefficients can only be estimated imprecisely, see Table 4.
} 
In the tobit model, the variable bid amount, $y_{i t}^{*}$, is specified as

$$
y_{i t}^{*}=x_{i t} \beta+\epsilon_{i t}
$$

where

$$
\epsilon_{i t} \sim N\left(0, \sigma^{2}\right)
$$

and the observed bid amount is

$$
y_{i t}= \begin{cases}y_{i t}^{*} & \text { if } y_{i t}^{*}>0 \\ 0 & \text { if } y_{i t}^{*} \leq 0 .\end{cases}
$$

Notice, that the tobit model uses both, the probability that $y_{i t}=0$ (given $x_{i t}$ ) and the distribution of $y_{i t}$ given that it is positive. This can be illustrated by the log likelihood function

$$
\ln \mathrm{L}=\sum_{y_{i t}>0}-\frac{1}{2}\left[\ln (2 \pi)+\ln \sigma^{2}+\frac{\left(y_{i t}-x_{i t}^{\prime} \beta\right)^{2}}{\sigma^{2}}\right]+\sum_{y_{i t}=0} \ln \left[1-\Phi\left(\frac{x_{i t}^{\prime} \beta}{\sigma}\right)\right]
$$

where $\Phi$ is the standard normal distribution. The first part of the log likelihood function represents the information of the conventional regression on the uncensored observations while the second part corresponds to the probit model describing a bank's participation decision. Obviously, the tobit estimation uses the full set of available information and hence will generally lead to more efficient estimates. Following Greene (2002), the marginal effects for the tobit model are given by

$$
\frac{\partial E\left[y_{i t} \mid x_{i t}\right]}{\partial x_{i t}}=\Phi\left(\frac{x_{i t}^{\prime} \beta}{\sigma}\right) \beta
$$

Table 7 shows the estimated coefficients and the resulting marginal effects from the tobit model explaining a bank's bid amount. We also display the results of a corresponding naive GLS panel regression which neglects the information contained in the zero bids. With respect to the marginal effects of the tobit model, the results from the GLS regression seem to be broadly in line with the tobit estimates. The general impression is, however, that the GLS model exaggerates the effects of interest rate expectations, opportunity cost and the reserve fulfillment. As expected, the standard deviations of the estimated coefficients are larger in the GLS model. The only exception refers to the variable reserve fulfillment whose significant coefficient implies that banks bid larger amounts when their liquidity needs are low. This implausible bidding behavior is not confirmed by the tobit analysis. 
Our findings are not in favor of a winner's curse effect, i.e. bidders do not reduce their bids significantly when volatility of the market interest rate increases. There is, however, a significant impact of the variable maturing allotment and the dummy variable end of period indicating that bidders bid more aggressively when their demand for refinancing is high and the danger of becoming squeezed increases.

The estimated coefficients of the term spread indicates that a bank's bid amount decreases when a negative term spread reveals that interest rates are expected to decrease. In line with the results obtained from the logit model, the economic significance of the term spread for the bid amount is rather small. Furthermore, the underbidding dummy capturing the Bundesbank's rate cut in August 1995 is far from being significant. This demonstrates that even in the week before an anticipated rate cut, the Bundesbank had no difficulties in supplying the appropriate volume of reserves through its repo auction. Thus, in contrast to the ECB's underbidding experience, interest rate expectations did not impede the Bundesbank's money market management.

\section{Size Effects on the Bid Amount}

Table 8 shows the results from the augmented tobit model that incorporates the interactions between the explanatory variables and the size dummies. Size effects are of particular relevance for monetary policy because central banks prefer 'fair' auction formats to avoid any violations of the principle of equal treatment. The tobit model estimates yield strong evidence in favor of a size effect concerning the impact of the term spread on a bank's bid amount in the repo auctions of the Bundesbank. Interestingly, the response of a bank's bid amount to interest rate expectations is most pronounced for small banks. This is in contrast to results obtained for the ECB's auctions where large banks seem to bid more informed than small banks, see e.g. Breitung and Nautz (2001). Note that this conflicting result might originate from neglecting the participation decision (i.e. the left-censoring of the data).

In terms of the other variables, allowing for size effects does not alter the main conclusions. In particular, the insignificant underbidding dummy and the small marginal effects of the term spread on the bid amount found in the augmented tobit model confirm that underbidding was not an issue in the repo auctions of the Bundesbank where no minimum bid rate was set. 


\section{Conclusions}

The crucial difference between the Bundesbank repo auctions and the ECB's current practise is the preannouncement of a minimum bid by the ECB. A major motivation for the current paper was to evaluate the consequences of this bidding constraint for the ECB's underbidding problem. Based on a unique data set of bidders' individual demand schedules, we perform a panel analysis of banks' bidding behavior in repo auctions of the Bundesbank. Specifically, we investigate how e.g. interest rate expectations, opportunity cost, volatility, and bidder size determine banks' participation decision and a bank's bid amount.

Analyzing a bank's bid amount, we explicitly account for the left-censoring of the bidding data by applying a tobit model that uses both, the probability of a bank's participation and the distribution of the bid amount given that it is positive. Using the full set of information, the tobit model delivers more efficient estimates. In the same vein, in our panel logit analysis of banks' participation decision, we did not remove the bidders never participating in an auction to avoid distorting effects on the estimated probabilities.

Our results indicate that interest rate expectations influence both, banks' participation and the submitted bid amount. However, in terms of the economic significance the impact of interest rate expectations is only modest. An important finding in this respect is that banks do not deviate significantly in their behavior prior to an anticipated interest rate cut of the Bundesbank. In the case of the ECB such interest rate expectations have led to underbidding and even bidder strikes. In the Bundesbank's auctions banks did not refrain from bidding but reacted to prevailing rate cut expectations by bidding at lower interest rates. Therefore, banks kept on bidding because the Bundesbank did not constrain bidders by a minimum bid rate. It appears that auctions without a minimum bid rate lead to more favorable outcomes than the current ECB auctions.

This result is of particular interest in the light of recent announcements by the ECB to reorganize its operational framework of monetary policy, see ECB (2003a). All these measures are designed to stop the underbidding problem by mitigating the role of interest rate expectations for banks' bidding. To that aim the maintenance period for required reserves will be determined by the meetings of the Governing councils. Moreover, the ECB emphasized that rate changes will only occur at those meetings. Finally, the maturity of the repos is reduced 
to one week. As a result there is no more overlapping of a repo in the next maintenance period in which the repo rate could possibly change.

Albeit the predictable success of these measures in fighting the underbidding problem, there are other problems coming along with the introduction of the new operational framework. The shorter maturity of the repos and the nonoverlapping maturities makes banks' reserve management more difficult. In particular, at the very last auction in the maintenance period, the risk of going out empty handed increases. This may increase bidding rates and banks' refinancing costs, see ECB (2003b). More importantly, however, the commitment of the ECB not to change the interest rates during the maintenance period makes the ECB's interest rate policy less flexible. Note that it was perceived as a major advantage of weekly repo auctions, that the central bank can change interest rates flexibly and even at short notice. For example, situations like September 11 or the war in Iraq may require to react immediately. Therefore, the credibility of the ECB's interest rate commitment could be an issue.

To sum up, we do not doubt that the ECB's measures will serve the purpose to prevent banks from underbidding. Still, in light of the new measures' caveats, our results suggest that abandoning the minimum bid rate would have been another feasible solution. In the ECB's current monetary policy setup, the minimum bid rate is the key interest rate that sets a floor for short-term interest rates and signals the policy intentions. However, recent contributions on monetary policy implementation show that neither steering money market rates nor policy signalling requires a minimum bid rate, see e.g. Guthrie and Wright (2000). 


\section{References}

Aldrich, J. and Nelson, F. (1984). Linear Probability, Logit, and Probit Models, Sage University Press, Beverly Hills.

Ayuso, J. and Repullo, R. (2001). Why did the banks overbid? An empirical model of fixed rate tenders of the European Central Bank, Journal of International Money and Finance 20: 857-870.

Bjonnes, G. H. (2001). Winner's curse in discriminatory price auctions: Evidence from the Norwegian Treasury Bill auctions, Working paper, Stockholm Institute for Financial Research.

Breitung, J. and Nautz, D. (2001). The empirical performance of the ECB's repo auctions: Evidence from aggregated and individual bidding data, Journal of International Money and Finance 20: 839-856.

ECB (2001). Bidding behavior of counterparties in the Eurosystem's regular open market operations, Monthly Bulletin (October): 51-63.

ECB (2003a). Annual Report, 2002, European Central Bank, Frankfurt am Main.

ECB (2003b). Summary of comments received on the measures proposed to improve the operational framework for monetary policy, www.ecb.int.

Greene, W. H. (2002). Econometric Analysis, fifth edn, Prentice Hall, New Jersey.

Guthrie, G. and Wright, J. (2000). Open mouth operations, Journal of Monetary Economics 46(2): 489-516.

Manna, M. (2002). Using money market rates to assess the alternatives of fixed vs. variable rate tenders: The lesson from 1989-1998 data for Germany, Working Paper 186, European Central Bank.

Nautz, D. (1997). How auctions reveal information: A case study on German repo rates, Journal of Money, Credit, and Banking 29(1): 17-25.

Nautz, D. (1998). Banks' demand for reserves when future monetary policy is uncertain, Journal of Monetary Economics 42(1): 161-183. 
Nautz, D. and Oechssler, J. (2003). The repo auctions of the European Central Bank and the vanishing quota puzzle, Scandinavian Economic Journal (forthcoming).

Nyborg, K. G., Bindseil, U. and Strebulaev, I. A. (2002). Bidder behavior and performance in repo auctions: The case of the Eurosystem, working paper 157, European Central Bank.

Nyborg, K. G., Rydqvist, K. and Sundaresan, S. (2002). Bidder behavior in multiunit auctions: Evidence from Swedish Treasury Auctions, Journal of Political Economy 110: $394-425$.

Nyborg, K. G. and Strebulaev, A. (2001). Collateral and short squeezing of liquidity in fixed rate tenders, Journal of International Money and Finance 20: 769-792.

Scalia, A. and Ordine, M. (2002). New evidence on money market integration in the Euro area: A panel study on banks' participation in the Eurosystem auctions, mimeo, Banca d'Italia. 


\section{A The expected stop out rate of the auction}

Using weekly observations from April to November 1995, we found that the stop out rate $(r)$ and the interbank overnight rate $(i)$ are cointegrated with a stationary spread, see Nautz (1997). As a consequence, the expected stop out rate is derived from an error correction equation which is estimated as follows:

$$
\begin{gathered}
\Delta r_{t}=\underset{(1.92)}{0.007}-\underset{(3.20)}{0.121}(r-i)_{t-1}+\underset{(5.71)}{0.662 \Delta r_{t-1}}+\widehat{\varepsilon}_{t} \\
R^{2}=0.62, \quad Q(4)=1.26 \quad \text { No. of observ.: } 31
\end{gathered}
$$

Notes: The t-values are reported in parenthesis.

\section{B Figures and Tables}

Figure 1: Interest rates in the German money market

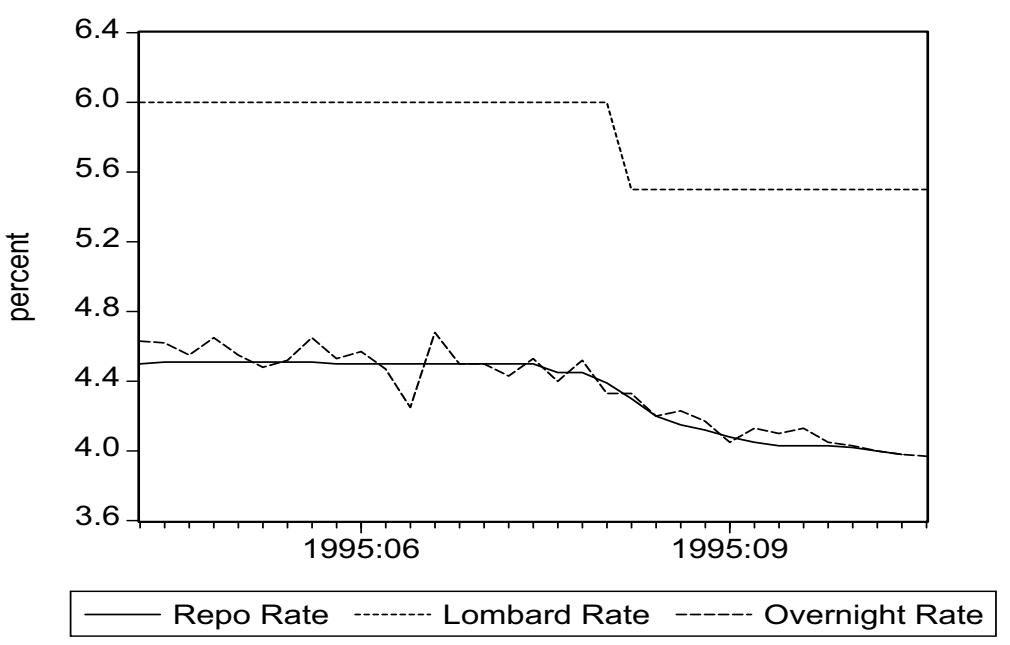

Notes: The repo rate corresponds to the stop out rate of the auction. The Lombard rate is the Bundesbank's key interest rate of the marginal lending facility which was lowered in August 1995. The overnight rate refers to the bidding days of the 33 auctions covered by our sample period. Source: Deutsche Bundesbank. 
Table 1: Distribution of Average Bid Volume

\begin{tabular}{lcc}
\hline \hline $\begin{array}{l}\text { Bid Volume } \\
\text { (in Mio. DM) }\end{array}$ & No. of Banks & $\begin{array}{c}\text { Percent } \\
\text { (Cumulative) }\end{array}$ \\
\hline 0 & 100 & 36.36 \\
$1-100$ & 132 & 84.36 \\
\hline $101-500$ & 29 & 94.91 \\
$501-1000$ & 5 & 96.73 \\
\hline $1001-3000$ & 4 & 98.18 \\
$\geq 3000$ & 5 & 100.00 \\
\hline$\sum$ & 275 & \\
\hline \hline
\end{tabular}

Notes: The data refers to the 33 Bundesbank auctions covered by our sample period (April to November 1995).

Table 2: Distribution of Number of Bids

\begin{tabular}{lcc}
\hline \hline No. of bids & No. of bidders & $\begin{array}{c}\text { Percent } \\
\text { (Cumulative) }\end{array}$ \\
\hline 0 & 6248 & 69.25 \\
1 & 1315 & 83.33 \\
2 & 918 & 93.35 \\
3 & 445 & 98.36 \\
4 & 105 & 99.52 \\
5 & 44 & 100 \\
\hline$\sum$ & 9075 & \\
\hline \hline
\end{tabular}

Notes: The data refers to the 33 Bundesbank auctions covered by our sample period (April to November 1995). 
Table 3: Participation Frequency

\begin{tabular}{lcc}
\hline \hline No. of auctions & No. of banks & $\begin{array}{c}\text { Percent } \\
\text { (Cumulative) }\end{array}$ \\
\hline 0 & 100 & 36.23 \\
$1-5$ & 46 & 52.90 \\
$6-10$ & 26 & 62.32 \\
$11-15$ & 18 & 68.84 \\
$16-20$ & 13 & 73.55 \\
$21-25$ & 19 & 80.43 \\
$26-30$ & 22 & 88.41 \\
$31-33$ & 32 & 100.00 \\
\hline$\sum$ & 275 & \\
\hline \hline
\end{tabular}

Notes: The data refers to the 33 Bundesbank auctions covered by our sample period (April to November 1995).

Table 4: Bank Types

\begin{tabular}{|c|c|c|c|c|c|}
\hline Bank Type & Bank Category & $\begin{array}{l}\text { No. of } \\
\text { Banks }\end{array}$ & $\begin{array}{c}\text { Average Bid } \\
\text { Volume/Bank } \\
\text { (in Mio. DM) }\end{array}$ & $\begin{array}{c}\text { Average } \\
\text { Allotment/Bank } \\
(\text { in Mio. DM })\end{array}$ & $\begin{array}{c}\text { Participation } \\
\text { Rate }\end{array}$ \\
\hline Large & $\begin{array}{l}\text { Big banks } \\
\text { Land banks }\end{array}$ & 5 & 3490 & 1130 & $96.36 \%$ \\
\hline Medium & $\begin{array}{l}\text { Banks with special } \\
\text { functions } \\
\text { Regional instit. of } \\
\text { credit coop. } \\
\text { Regional banks } \\
\text { Building associations }\end{array}$ & 87 & 190 & 101 & $49.15 \%$ \\
\hline Small & $\begin{array}{l}\text { Credit cooperatives } \\
\text { Saving banks } \\
\text { Branches of foreign } \\
\text { banks }\end{array}$ & 183 & 23.9 & 13.1 & $21.71 \%$ \\
\hline
\end{tabular}

Notes: The data refers to 33 Bundesbank auctions in the period from April to November 1995. Bank categories correspond to the categorization by the Deutsche Bundesbank. 


\begin{tabular}{|c|c|c|c|}
\hline & $\begin{array}{l}\text { Random Effects } \\
\text { Estimation }\end{array}$ & Marginal Effects & $\begin{array}{l}\text { Conditional Fixed } \\
\text { Effects Estimation }\end{array}$ \\
\hline Term spread & $\begin{array}{l}8.19 \\
(5.16)\end{array}$ & 0.879 & $\begin{array}{c}8.70 \\
(5.48)\end{array}$ \\
\hline Underbidding dummy & $\begin{array}{c}0.36 \\
(1.20)\end{array}$ & - & $\begin{array}{c}0.30 \\
(0.97)\end{array}$ \\
\hline Spread & $\begin{array}{l}-11.57 \\
(-6.82)\end{array}$ & -1.242 & $\begin{array}{l}-12.14 \\
(-7.14)\end{array}$ \\
\hline Volatility & $\begin{array}{l}-0.19 \\
(-2.08)\end{array}$ & -0.020 & $\begin{array}{c}-0.20 \\
(-2.18)\end{array}$ \\
\hline Reserve fulfillment & $\begin{array}{c}0.68 \\
(0.55)\end{array}$ & - & $\begin{array}{c}1.11 \\
(0.90)\end{array}$ \\
\hline Maturing allotment & $\begin{array}{c}0.13 \\
(22.24)\end{array}$ & 0.014 & $\begin{array}{c}0.11 \\
(19.15)\end{array}$ \\
\hline End of period dummy & $\begin{array}{c}0.74 \\
(6.28)\end{array}$ & 0.060 & $\begin{array}{c}0.76 \\
(6.41)\end{array}$ \\
\hline \multicolumn{4}{|l|}{ Size dummies: } \\
\hline Large & $\begin{array}{c}2.51 \\
(1.57)\end{array}$ & & \\
\hline Medium & $\begin{array}{l}-4.58 \\
(-3.04)\end{array}$ & & \\
\hline Small & $\begin{array}{c}-5.82 \\
(-3.87)\end{array}$ & & \\
\hline Pseudo- $R^{2}$ & 0.1142 & & 0.1048 \\
\hline No. of observations & 8525 & & 4495 \\
\hline No. of groups & 275 & & 145 \\
\hline
\end{tabular}

Notes: The t-values of the parameter estimates are reported in parenthesis. For the significant parameters we calculated the marginal effects (see Equation 2) that indicate the economic significance of the variables by the usual elasticity interpretation. Note that the Conditional Fixed Effects estimation is restricted to banks which participate at least twice. The Pseudo- $R^{2}$ measure is calculated according to Aldrich and Nelson (1984). 
Table 6: The Participation Decision of an Individual Bank with Size Specific Regressors

\begin{tabular}{|c|c|c|c|}
\hline & $\begin{array}{l}\text { Coefficient } \\
\text { Estimate }\end{array}$ & $\begin{array}{c}H_{0}: \text { no size effect } \\
\text { (p-value })\end{array}$ & $\begin{array}{c}H_{0}: \text { zero effect } \\
(\mathrm{p} \text {-value })\end{array}$ \\
\hline Term spread/large banks & $20.36(0.98)$ & & \\
\hline Term spread/medium banks & $0.74(0.31)$ & 0.0002 & 0.0000 \\
\hline Term spread/small banks & $14.02(6.45)$ & & \\
\hline Underbidding dummy/large banks & $0.19(0.08)$ & & \\
\hline Underbidding dummy/medium banks & $0.12(0.26)$ & 0.7285 & 0.5392 \\
\hline Underbidding dummy/small banks & $0.60(1.45)$ & & \\
\hline Spread/large banks & $-20.71(-0.92)$ & & \\
\hline Spread/medium banks & $-4.65(-1.84)$ & 0.0018 & 0.0000 \\
\hline Spread/small banks & $-16.81(-7.17)$ & & \\
\hline Volatility/large banks & $-1.24(-1.06)$ & & \\
\hline Volatility/medium banks & $-0.13(-0.96)$ & 0.5788 & 0.1260 \\
\hline Volatility/small banks & $-0.24(-1.92)$ & & \\
\hline Reserve fulfillment/large banks & $1.60(0.12)$ & & \\
\hline Reserve fulfillment/medium banks & $-1.23(-0.67)$ & 0.3998 & 0.5626 \\
\hline Reserve fulfillment/small banks & $2.17(1.26)$ & & \\
\hline Maturing allotment/large banks & $0.02(0.40)$ & & \\
\hline Maturing allotment/medium banks & $0.12(13.67)$ & 0.0187 & 0.0000 \\
\hline Maturing allotment/small banks & $0.15(17.27)$ & & \\
\hline Period end dummy/large banks & $1.07(0.71)$ & & \\
\hline Period end dummy/medium banks & $0.66(3.59)$ & 0.8521 & 0.0000 \\
\hline Period end dummy/small banks & $0.78(5.00)$ & & \\
\hline \multicolumn{4}{|l|}{ Size dummies } \\
\hline Large & $-6.23(-0.40)$ & & \\
\hline Medium & $-1.75(-0.79)$ & 0.1123 & 0.0000 \\
\hline Small & $-8.12(-3.89)$ & & \\
\hline Pseudo- $R^{2}$ & 0.1094 & & \\
\hline No. of observations & 8525 & & \\
\hline No. of groups & 275 & & \\
\hline
\end{tabular}

Notes: The size specific regressors are obtained from the interaction of the explanatory variables $x_{i t}$ with size dummies large, medium, and small (see Table 4). The t-values of the parameter estimates are reported in parenthesis. The second column shows the p-values from a $\chi^{2}$ distributed Wald-test with the null hypothesis that there are no size effects. The third column reports the p-values from a $\chi^{2}$ distributed Wald-test with the hypothesis that the interaction terms being jointly equal to zero. The Pseudo- $R^{2}$ is calculated according to Aldrich and Nelson (1984). 
Table 7: The Determinants of a Bank's Bid Amount: A Panel Analysis

\begin{tabular}{|c|c|c|c|}
\hline & $\begin{array}{c}\text { Tobit Model } \\
\text { Coefficient Estimate }\end{array}$ & $\begin{array}{l}\text { Tobit Model } \\
\text { Marginal Effect }\end{array}$ & $\begin{array}{l}\text { Random Effects GLS } \\
\text { Coefficient Estimate }\end{array}$ \\
\hline Term spread & $\begin{array}{l}11.59 \\
(4.23)\end{array}$ & 1.00 & $\begin{array}{c}1.43 \\
(4.27)\end{array}$ \\
\hline Underbidding dummy & $\begin{array}{c}0.32 \\
(0.61)\end{array}$ & - & $\begin{array}{c}0.05 \\
(1.97)\end{array}$ \\
\hline Spread & $\begin{array}{l}-16.55 \\
(-7.82)\end{array}$ & -1.43 & $\begin{array}{l}-1.94 \\
(-5.40)\end{array}$ \\
\hline Volatility & $\begin{array}{l}-0.24 \\
(-1.50)\end{array}$ & - & $\begin{array}{c}0.01 \\
(0.38)\end{array}$ \\
\hline Reserve fulfillment & $\begin{array}{c}1.32 \\
(0.61)\end{array}$ & - & $\begin{array}{c}0.67 \\
(2.39)\end{array}$ \\
\hline Maturing allotment & $\begin{array}{c}0.23 \\
(20.41)\end{array}$ & 0.02 & $\begin{array}{c}0.01 \\
(7.39)\end{array}$ \\
\hline End of period dummy & $\begin{array}{c}0.93 \\
(4.61)\end{array}$ & 0.08 & $\begin{array}{l}-0.08 \\
(-1.13)\end{array}$ \\
\hline \multicolumn{4}{|l|}{ Size dummies } \\
\hline Large & $\begin{array}{c}3.95 \\
(1.50)\end{array}$ & & - \\
\hline Medium & $\begin{array}{l}-8.98 \\
(-3.43)\end{array}$ & & $\begin{array}{l}-3.46 \\
(-5.10)\end{array}$ \\
\hline Small & $\begin{array}{l}-12.70 \\
(-4.82)\end{array}$ & & $\begin{array}{l}-4.80 \\
(-7.14)\end{array}$ \\
\hline Constant & - & & $\begin{array}{c}21.01 \\
(28.61)\end{array}$ \\
\hline Pseudo- $R^{2}$ & 0.161 & & 0.062 \\
\hline No. of observations & 8525 & & 2625 \\
\hline No. of groups & 275 & & 275 \\
\hline
\end{tabular}

Notes: The t-values of the parameter estimates are reported in parenthesis. For the significant parameters we calculated the marginal effects (see Equation 5) that indicate the economic significance of the variables by the the usual elasticity interpretation. There were 5900 left-cencored observations in our sample. Note that for the linear Random effects GLS estimation all left-censored observations are dropped. The Pseudo- $R^{2}$ measure is calculated according to Aldrich and Nelson (1984). 
Table 8: The Determinants of a Bank's Bid Amount: Tobit Model Estimation with Bank Size Specific Regressors

\begin{tabular}{|c|c|c|c|}
\hline & $\begin{array}{l}\text { Coefficient } \\
\text { Estimate }\end{array}$ & 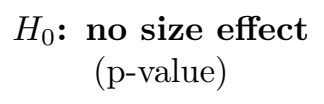 & $\begin{array}{l}H_{0}: \text { zero effect } \\
\quad(\mathrm{p} \text {-value })\end{array}$ \\
\hline Term spread/large banks & $5.19(0.74)$ & & \\
\hline Term spread/medium banks & $1.82(0.89)$ & 0.0004 & 0.0000 \\
\hline Term spread/small banks & $12.91(6.63)$ & & \\
\hline Underbidding dummy/large banks & $-0.70(-0.55)$ & & \\
\hline Underbidding dummy/medium banks & $-0.01(-0.04)$ & 0.5847 & 0.7014 \\
\hline Underbidding dummy/small banks & $0.42(1.06)$ & & \\
\hline Spread/large banks & $-5.64(-0.75)$ & & \\
\hline Spread/medium banks & $-6.15(-2.82)$ & 0.0076 & 0.0000 \\
\hline Spread/small banks & $-15.30(-7.37)$ & & \\
\hline Reserve fulfillment/large banks & $0.09(0.02)$ & & \\
\hline Reserve fulfillment/medium banks & $-0.57(-0.36)$ & 0.5056 & 0.6187 \\
\hline Reserve fulfillment/small banks & $2.02(1.29)$ & & \\
\hline Volatility/large banks & $-0.23(-0.57)$ & & \\
\hline Volatility/medium banks & $-0.36(-0.30)$ & 0.2357 & 0.0428 \\
\hline Volatility/small banks & $-0.31(-2.78)$ & & \\
\hline Maturing allotment/large banks & $0.03(1.48)$ & & \\
\hline Maturing allotment/medium banks & $0.13(17.90)$ & 0.0000 & 0.0000 \\
\hline Maturing allotment/small banks & $0.20(23.57)$ & & \\
\hline End of period dummy/large banks & $0.09(0.18)$ & & \\
\hline End of period dummy/medium banks & $0.59(3.91)$ & 0.5445 & 0.0000 \\
\hline End of period dummy/small banks & $0.67(4.77)$ & & \\
\hline \multicolumn{4}{|l|}{ Size dummies } \\
\hline Large & $4.78(0.74)$ & & \\
\hline Medium & $-1.99(-1.04)$ & 0.0103 & 0.0001 \\
\hline Small & $-8.34(-4.40)$ & & \\
\hline Pseudo- $R^{2}$ & 0.228 & & \\
\hline No. of observations & 8525 & & \\
\hline No. of groups & 275 & & \\
\hline
\end{tabular}

Notes: The size specific regressors are obtained from the interaction of the explanatory variables $x_{i t}$ with size dummies large, medium, and small (see Table 4). The t-values of the parameter estimates are reported in parenthesis. Note that there were 5900 left-cencored observations in our sample. For further information see Table 6 . 


\section{The following papers have been published since 2002:}

\begin{tabular}{|c|c|c|c|}
\hline January & 2002 & $\begin{array}{l}\text { Rent indices for housing in West } \\
\text { Germany } 1985 \text { to } 1998\end{array}$ & $\begin{array}{l}\text { Johannes Hoffmann } \\
\text { Claudia Kurz }\end{array}$ \\
\hline January & 2002 & $\begin{array}{l}\text { Short-Term Capital, Economic Transform- } \\
\text { ation, and EU Accession }\end{array}$ & $\begin{array}{l}\text { Claudia M. Buch } \\
\text { Lusine Lusinyan }\end{array}$ \\
\hline \multirow[t]{2}{*}{ January } & 2002 & $\begin{array}{l}\text { Fiscal Foundation of Convergence } \\
\text { to European Union inLászló Halpern }\end{array}$ & \\
\hline & & Pre-Accession Transition Countries & Judit Neményi \\
\hline \multirow[t]{2}{*}{ January } & 2002 & Testing for Competition Among & \\
\hline & & German Banks & Hannah S. Hempell \\
\hline January & 2002 & $\begin{array}{l}\text { The stable long-run CAPM and } \\
\text { the cross-section of expected returns }\end{array}$ & Jeong-Ryeol Kim \\
\hline \multirow[t]{2}{*}{ February } & 2002 & $\begin{array}{l}\text { Pitfalls in the European Enlargement } \\
\text { Process - Financial Instability and }\end{array}$ & \\
\hline & & Real Divergence & Helmut Wagner \\
\hline February & 2002 & $\begin{array}{l}\text { The Empirical Performance of Option } \\
\text { Based Densities of Foreign Exchange }\end{array}$ & $\begin{array}{l}\text { Ben R. Craig } \\
\text { Joachim G. Keller }\end{array}$ \\
\hline February & 2002 & $\begin{array}{l}\text { Evaluating Density Forecasts with an } \\
\text { Application to Stock Market Returns }\end{array}$ & $\begin{array}{l}\text { Gabriela de Raaij } \\
\text { Burkhard Raunig }\end{array}$ \\
\hline
\end{tabular}

February 2002 Estimating Bilateral Exposures in the German Interbank Market: Is there a Danger of Contagion?

Christian Upper Andreas Worms

February 2002 The long-term sustainability of public finance in Germany - an analysis based on generational accounting Bernhard Manzke 
2002 March $\quad$ The pass-through from market interest rates to bank lending rates in Germany Mark A. Weth

April 2002 Dependencies between European stock markets when price changes are unusually large

Sebastian T. Schich

May $2002 \quad$ Analysing Divisia Aggregates for the Euro Area

Hans-Eggert Reimers

May $2002 \quad$ Price rigidity, the mark-up and the dynamics of the current account

Giovanni Lombardo

June $2002 \quad$ An Examination of the Relationship

Between Firm Size, Growth, and

Liquidity in the Neuer Markt

Julie Ann Elston

June 2002 Monetary Transmission in the

New Economy: Accelerated Depreci-

ation, Transmission Channels and

Ulf von Kalckreuth

the Speed of Adjustment

Jürgen Schröder

$2002 \quad$ June $\quad$ Central Bank Intervention and

Exchange Rate Expectations -

Evidence from the Daily

DM/US-Dollar Exchange Rate

Stefan Reitz

June $2002 \quad$ Monetary indicators and policy rules

in the P-star model

Karl-Heinz Tödter

July $2002 \quad$ Real currency appreciation in accession countries: Balassa-Samuelson and investment demand

Christoph Fischer

August $2002 \quad$ The Eurosystem's Standing Facilities in a General Equilibrium Model of the European Interbank Market Jens Tapking 
$2002 \quad$ Imperfect Competition, Monetary Policy

and Welfare in a Currency Area Giovanni Lombardo

August $2002 \quad$ Monetary and fiscal policy rules in a

model with capital accumulation and

potentially non-superneutral money

Leopold von Thadden

September 2002 Dynamic Q-investment functions for

Germany using panel balance sheet data

and a new algorithm for the capital stock Andreas Behr

at replacement values

Egon Bellgardt

October 2002 Tail Wags Dog? Time-Varying Informa-

Christian Upper

tion Shares in the Bund Market

Thomas Werner

October 2002 Time Variation in the Tail Behaviour of

Thomas Werner

Bund Futures Returns

Christian Upper

November $2002 \quad$ Bootstrapping Autoregressions with

Conditional Heteroskedasticity of

Unknown Form

Sílvia Gonçalves

Lutz Kilian

November 2002 Cost-Push Shocks and Monetary Policy

in Open Economies

Alan Sutherland

November $2002 \quad$ Further Evidence On The Relationship

Between Firm Investment And

Robert S. Chirinko

Financial Status

Ulf von Kalckreuth

November 2002 Genetic Learning as an Explanation of

Stylized Facts of Foreign Exchange

Thomas Lux

Markets

Sascha Schornstein

December 2002 Wechselkurszielzonen, wirtschaftlicher

Aufholprozess und endogene Realign-

mentrisiken *

Karin Radeck

* Available in German only. 
December 2002 Optimal factor taxation under wage bargaining - a dynamic perspective

January 2003 Testing mean-variance efficiency in CAPM with possibly non-gaussian errors: an exact simulation-based approach

January $2003 \quad$ Finite-sample distributions of self-normalized sums

January 2003 The stock return-inflation puzzle and the asymmetric causality in stock returns, inflation and real activity

February $2003 \quad$ Multiple equilibrium overnight rates in a dynamic interbank market game

February 2003 A comparison of dynamic panel data estimators: Monte Carlo evidence and an application to the investment function

2003 A Vectorautoregressive Investment Model (VIM) And Monetary Policy

Transmission: Panel Evidence From German Firms

2003 The international integration of money markets in the central and east European accession countries: deviations from covered interest parity, capital controls and inefficien- Sabine Herrmann Cies in the financial sector Axel Jochem

March 2003 The international integration of foreign exchange markets in the central and east European accession countries: speculative efficiency, transaction costs and exchange rate premiums
Jeong-Ryeol Kim

Erkki Koskela

Leopold von Thadden

Marie-Claude Beaul Jean-Marie Dufour

Lynda Khalaf

Jeong-Ryeol Kim

Jens Tapking

Andreas Behr

Joerg Breitung

Robert S. Chirinko

Ulf von Kalckreuth
Sabine Herrmann

Axel Jochem 


\begin{tabular}{|c|c|c|c|}
\hline \multirow[t]{3}{*}{ March } & \multirow[t]{3}{*}{2003} & Determinants of German FDI: & Claudia Buch \\
\hline & & New Evidence from & Jörn Kleinert \\
\hline & & Micro-Data & Farid Toubal \\
\hline \multirow[t]{2}{*}{ March } & \multirow[t]{2}{*}{2003} & On the Stability of & \\
\hline & & Different Financial Systems & Falko Fecht \\
\hline \multirow[t]{3}{*}{ April } & \multirow[t]{3}{*}{2003} & Determinants of German Foreign & \\
\hline & & Direct Investment in Latin American and & \\
\hline & & Asian Emerging Markets in the 1990s & Torsten Wezel \\
\hline \multirow[t]{2}{*}{ June } & \multirow[t]{2}{*}{2003} & $\begin{array}{l}\text { Active monetary policy, passive fiscal } \\
\text { policy and the value of public debt: }\end{array}$ & \\
\hline & & some further monetarist arithmetic & Leopold von Thadden \\
\hline \multirow[t]{3}{*}{ June } & \multirow[t]{3}{*}{2003} & Bidder Behavior in Repo Auctions & Tobias Linzert \\
\hline & & without Minimum Bid Rate: & Dieter Nautz \\
\hline & & Evidence from the Bundesbank & Jörg Breitung \\
\hline
\end{tabular}




\section{Visiting researcher at the Deutsche Bundesbank}

The Deutsche Bundesbank in Frankfurt is looking for a visiting researcher. Visitors should prepare a research project during their stay at the Bundesbank. Candidates must hold a $\mathrm{Ph} \mathrm{D}$ and be engaged in the field of either macroeconomics and monetary economics, financial markets or international economics. Proposed research projects should be from these fields. The visiting term will be from 3 to 6 months. Salary is commensurate with experience.

Applicants are requested to send a $\mathrm{CV}$, copies of recent papers, letters of reference and a proposal for a research project to:

Deutsche Bundesbank

Personalabteilung

Wilhelm-Epstein-Str. 14

D - 60431 Frankfurt

GERMANY 


